Cordingley, A \& Montini, C. (2015). Genetic translation studies: an emerging discipline. Linguistica Antverpiensia, New Series: Themes in Translation Studies, 14, 1-18.

\title{
Genetic translation studies: An emerging discipline
}

\author{
Anthony Cordingley \\ Université Paris 8 - Vincennes-Saint-Denis, France \\ Institut des textes et manuscrits modernes (ENS-CNRS), France \\ University of Sydney, Australia \\ anthony.cordingley@univ-paris8.fr
}

\section{Chiara Montini}

Institut des textes et manuscrits modernes (ENS-CNRS), France montini.chiara@gmail.com

This article charts the emergence of a new form of translation research that we term genetic translation studies. It explores the foundations of this approach in the French school of critique génétique, which developed a methodology for studying the drafts, manuscripts and other working documents (avant-textes) of modern literary works with the aim of revealing the complexity of the creative processes engaged in their production. This methodology draws upon different theoretical and interdisciplinary approaches (poetic, linguistic, philosophical, psychoanalytical, phenomenological, etc.) and has since been adapted to the study of other media, including music, cinema, photography, painting, architecture, and the translated text. This article analyses how genetic approaches have been applied to translated texts by both genetic critics and translation scholars. It highlights, furthermore, the opportunities as well as the challenges for literary and other forms of translation research when a genetic approach is adopted.

Over the past decade a new field of research has emerged that may be termed "genetic translation studies". It analyses the practices of the working translator and the evolution, or genesis, of the translated text by studying translators' manuscripts, drafts and other working documents. Genetic translation studies focuses therefore on the transformations of the translated text during the process of its composition. It may, like cognitive translation studies, also attempt to deduce the strategies and mental operations of the working translator. Yet its methodology differs from the cognitive approach because its object is the textual evidence of the activity of translation rather than the translating subject. In particular, genetic translation studies have developed within literary translation studies through the application of the methodology of critique génétique 
- which is known in English as "genetic criticism" or "manuscript genetics" - to translated texts. Here, scholars are typically drawn to the genesis of certain translations for their aesthetic or literary value, long after the creative energies that flared at the time of composition have faded.

Genetic criticism offers a methodology with which to gain a window upon the writer's workshop. It maintains that the published text is but one phase in the text's evolution, and that this process of textual transformation continues well after the work's publication through its reeditions, its retranslations and its different reception by heterogeneous communities of readers. This issue of Linguistica Antverpiensia aims to take stock of the diversity of genetic approaches currently applied to the study of translation and to generate a dialogue between these and other scientific disciplines. It attempts, also, to provoke genetic critics to revaluate their methodology in light of the specificities of translating and the translated text. Equally, it aims to stimulate translation studies research into the contingencies of the translated text and the variety of strategies employed during the various phases of its composition.

\section{Genetic criticism: A brief overview}

Critique génétique was born in France in the mid-1960s, on the cusp of the shift from structuralist to post-structuralist conceptions of text and in an intellectual climate where the authority of the author as well as the stability of both the published oeuvre and the written word were brought into question (Barthes, 1971). While post-structuralist critiques of text confronted assumptions of the text's stability with the evolving synchronic and intertextual networks upon which it depends, genetic critics sought to challenge the sacrosanct authority of the published text by showing how it is but one phase in a continuum of textual creation (Bellemin-Noël, 1972). With this move they also brought into question a model of authority inherited from the Romantic period: revealing the labour of the text's creation undermines the much-vaunted myth of the author's genius. One could no longer hold that great works of literature witness the channelling of metaphysical essence through the author in the moment of inspiration. Genetic studies chart the diachronic phases of a text's composition through the constitution of what is termed the "dossier génétique". The genetic dossier includes the work's avant-textes (the French term has carried over into English) (Ferrer, 2010a), which are classified as either "exogenetic", being sources for the work (notes, articles, images and books), or "endogenetic", that is, produced during the text's composition (manuscripts, drafts, corrected page proofs) (DebrayGenette, 1979). While these categories provide neat distinctions for researchers, they are recognized to be imperfect, for there are often cases where the division between exogenesis and endogenesis is blurred. 
The methodology of genetic criticism began in the late 1960s when Louis Hay was working on the manuscripts of Henri Heine. Hay founded what was to become the Institut des textes et manuscrits modernes (ITEM) in Paris, where scholars such as Pierre-Marc de Biasi, Jean-Louis Lebrave, Daniel Ferrer and Almuth Grésillon developed its methodology. They sought to distinguish genetic criticism from traditional philology and biographical literary criticism (Ferrer, 2002, 2010b; Lebrave, 1992), asserting that its object of study is not the "finished" text but the "work in progress". Unlike Italian philology, and even its later concept of "variantistica" (Contini, 1971), which is closer to genetic criticism in its study of the writing process, genetic critics do not consider the published text to be the complete work, but rather the last state in a continuum of textual becoming. They do not align themselves with Lachmanian methods and they have sought to distance themselves from AngloAmerican textual scholarship (e.g., Bowers, 1966; Greetham, 1992/1994), which has traditionally focused on reconstituting a most correct, ideal or best possible version/edition of the text through manuscript research. While a published genetic edition may be the outcome of genetic research, genetic critics claim that the focus of their research is the classification and analysis of the processes governing the text's coming into being, the mapping out and understanding of the different phases of its composition (de Biasi, 2011; Ferrer, 2011; Grésillon, 1994; Hay, 1993, 1998; Willemart, 2007; a useful collection of genetic critical texts in English is Deppman, Ferrer and Groden's Genetic Criticism: Texts and Avant-Textes [2004]). Yet Van Hulle (2014, pp. 8-11) points out that textual scholars do not neglect such dimensions, and that while it was important in the cultural climate of French post-structuralism for genetic critics to distance themselves from traditional philology, which was stigmatised by its search for origins and authorial intentions, it is often difficult to discern the difference between genetic criticism and textual scholarship as each is currently practised.

Today, genetic approaches to the study of literature are practised in many languages all over the world. ${ }^{1}$ At ITEM this method is currently being developed outside of its traditional field of literary studies, such that alongside teams of scholars working on canonical authors such as Flaubert, Joyce, Nietzsche, Proust, Valéry and Zola are those working on the genesis of philosophical and linguistic texts, on autobiography and correspondence. The methodology has also been adapted to different media - ITEM comprises teams devoted to the genetic study of art works and architectural objects, of films and photography. In 2010, a group of scholars formed a team devoted to translated and multilingual texts, although genetic translation studies was practised at ITEM from the early 1990s, when scholars working on the Paul Valéry archives were presented with manuscripts of his translations. In 1995 they published a collection of articles Génétique \& Traduction (Bourjea) after a conference at Arles in France devoted to the question. Yet only in the past 
decade has momentum for genetic translation studies been building. Recent conferences have been held in Brazil - "I Simpósio Internacional de Crítica Genética, Tradução Intersemiótica e Audiovisual" (Nuproc, 2011) and "II Simpósio Internacional de Crítica Genética e Tradução" (Universidade Federal de Santa Caterina, 2014) — as well as in France"La traduction et la question du choix" (Paris, ENS, 2014; proceedings, Montini, 2015) and "Les grands traducteurs dans les archives de l'IMEC" (IMEC, Caen, 2015). The European Society for Textual Scholarship devoted its 6th International Conference to "Texts beyond borders: Multilingualism and Textual Scholarship", held in Brussels in 2009, which resulted in a special issue of Variants (Dillen, Macé, \& Van Hulle, 2012). Genetic translation studies has been the subject of special journal issues in the fields of genetic criticism (Genesis, 2014) and Italian studies (Transalpina, 2015). The technique has been used to discover instances of collaboration and authorial intervention in translation (Anokhina, 2015, Hartmann, 2000). In Brazil, the question has been addressed in articles (Grando, 2001), an edited collection (Romanelli, Soares, \& Souza 2013), and a special issue of Manuscrítica (Gama \& Amigo Pino, 2011). Important articles have appeared in journals of translation studies (Munday, 2013; Scott, 2006). Furthermore, recent monographs have offered in-depth reflection and analysis of translation genetics in English, French, and Portuguese (Paret-Passos, 2011; Romanelli, 2013a; Sardin, 2002; Van Hulle \& Weller, 2014).

These recent studies do not treat the writing of translation as less prestigious or complex than that of its source text but as writing which develops strategies to respond to different sets of conditions. Whereas this field is in its infancy, studies to date suggest that one of the great strengths of a genetic approach to translation is its capacity to problematize the much-debated "agency" of the translator. Indeed, the studies in this issue of Linguistica Antverpiensia demonstrate that the degree to which a translator exercises his/her creativity in translation, not to mention his/her engaging in domesticating or foreignizing strategies when translating, shifts during the translation's genesis. Discussion of these questions in translation studies often assumes that a translator adopts a position or strategy to which s/he remains committed. However, by studying the process of a translation's composition, one observes translators using different strategies at different moments in the composition of their translation. To ignore the history of a translation's creation blinds one to the different practices employed between the translator's first efforts, for which the source text may be kept close at hand, and the later revising phases, where a translator may exercise greater "agency", using his/her discretion to intervene in the text. In this case, a translation that may have begun as highly source oriented may finally demonstrate great freedom from its source and creativity. Or a genetic study may reveal the opposite strategy: a translator may permit him/herself a degree of freedom and play in the drafts which he/she feels 
must be censored from the published work. To claim, in either case, that the translator is a translator who exercises the strategy evident in the published text is thus to describe but partially the nature of his or her work.

\section{The search for origins in translation and genetic criticism}

Reconsidering genetic criticism through translation allows one to rethink the premises of philological research and the question of its muchcontested search for origins. The French scholar Henri Meschonnic underlined the centrality of translation in Western culture when he began his courses, "Tout est traduction". This sentiment is echoed in Gianfranco Folena's Volgarizzare e tradurre: "in principio fuit interpres" (1991, p. VII). Folena detects translation at the origin of every literary tradition and thus reformulates the old cliché of the traduttore/traditore into traduzione/tradizione (translation/tradition). Tradition is translation because without translation there can be no tradition, and translation is tradition in the sense that it is the historical and present transfer of cultural heritage. The history of cultural traditions is the history of translation.

Translation is at once origin and transmission. To consider translation as origin does not introduce the notion of equivalence of origins and textual "originals". Nor does it subsume translation into a hierarchical logic of subordination, posteriority and defective repetition. It affirms the need for originality in every act of literary translation, which, by definition, cannot merely replicate or reproduce anterior forms. It also suggests the parity between writing and translating that Proust felt when he designated the writer a translator and an artisan: "Le devoir et la tâche d'un écrivain sont ceux d'un traducteur" (Proust, 1987-1988, p. 45), which was reformulated by Samuel Beckett (1970/1976): "The artist has acquired his text: the artisan translates it. 'The duty and task of a writer (not an artist, a writer) are those of a translator"” (p. 84).

In this lineage, the present issue of Linguistica Antverpiensia investigates the process of translating as the movement of cultural history and tradition by tracing its transformations from one language and culture to another. The articles in this issue propose different interpretations of translation as text (the genesis of an independent text) and/or post-text (the next evolution in the genesis of the source text). Genetic criticism has given little attention to the post-text while at the same time much attention in recent translation studies has been directed towards establishing the independence of the translated text. The study of the translator's avant-textes reveals the diachronic momentum and temporal particularity of the translation's becoming, its acquiring its independence. Yet the avant-textes also bear witness to the post-textual transformation of the published work. Indeed, a genetics of translation shifts the attention 
of genetic criticism from avant-texte to post-text and the focus of translation studies from the published translation to its genesis, revealing at the same time the varying strategies used by the translator at different moments of the text's composition.

\section{Challenges to a genetic translation studies}

As necessary as genetic criticism has been to challenging the Romantic heritage in literary studies, so too a genetics of translation is needed to render visible certain complexities of the compositional process. Yet genetic scholars have been slow to adapt their methodology to the translated text, and this neglect has left them vulnerable to the accusation that they too have been victim to the worshipping of the very original of which they have been so critical. Only when the translator had acquired independent "symbolic power" in the cultural field, to adopt Bourdieu's terminology, could some traction be gained for the idea that translators' avant-textes were worthy objects of study. In reality, however, a number of circumstances have conspired against the meeting of these two fields of research.

Genetic scholars typically work outside the field of translation studies, and they have only recently begun to participate in the debates that have sought to rescue translation from its dismissal as a derivative and secondary activity. ${ }^{2}$ The meeting of critique génétique and translation studies has suffered from the fact that French traductologie consolidated itself as a discipline relatively late and has proven to be, for many cultural reasons, slow to engage wholeheartedly in the debates of international translation studies, which uses English as its lingua franca. Introducing one of the first collections of articles dedicated to the genetics of translation, a 2014 special issue of the journal of genetic criticism, Genesis, Fabienne Durand-Bogaert (2014a, p. 7) remarks that it was only in the 1970s and 80s that translation studies in France became an autonomous discipline that was no longer confined to the periphery of linguistics, stylistics, and comparative literature. More fundamentally, however, for a genetics of translation to emerge it needed to overcome the prejudice that translations are both ephemeral and historically contingent. They were considered ephemeral not only because the translator was overlooked by history, existing in the shadow of the author, but because his or her work appeared to exist only in the transitory present. Whereas the author's text was regarded as definitive and permanent, translations were seen to multiply, be corrected, revised and updated; they were continually recontextualized by researchers.

The ideological bias that led genetic scholars to neglect translation has also had serious material consequences for the very possibility of conducting genetic translation research. Manuscripts have, of course, been collected since the middle ages, yet extant autograph manuscripts 
dating from before the eighteenth century are very rare, for most surviving manuscripts are typically copies produced by scribes and the scriptorium. And yet the modern obsession with originality values autograph material above all else. The fascination with collecting authors' manuscripts has been traced to Victor Hugo, who is said to have protected his drafts as if his life depended on it, and was the first to bequeath them to the Bibliothèque nationale de France (de Biasi, 2011, pp. 19-20). Hugo's gesture was and continues to be repeated by a great number of writers in France and abroad, while institutions and archives have amassed vast and valuable collections of such material.

However, the cult of genius that emerged in the nineteenth century and fuelled the desire to collect authors' manuscripts did not extend to translators, who had to wait until the next century to attract the attention of collectors and archivists. Somewhat ironically, the only genetic translation research that has been possible is almost invariably that which has been able to reinforce the cultural standing of canonical authors or persons of historical interest for the very reason that only these person's translation papers were collected. Contrary to Walter Benjamin's (1991) assertion that "even the greatest translation is determined to become part of the growth of its own language and eventually to perish with its renewal" (p. 153), some translations have stood the test of time. They are almost always the translations of those whose position in the cultural field is already legitimated by their literary authorship. To consider only the Western tradition, one thinks immediately of author-translators such as Artaud, Baudelaire, Beckett, Benjamin, Chateaubriand, Cicero, Dryden, Fitzgerald, Hölderlin, Mallarmé, Milton, Nabokov, Pavese, Petrarch, Pound, and Valéry. Indeed, for a long time, only the translation manuscripts of author-translators were not considered disposable, devoid of artistic, cultural and commercial value, subordinate to "original" writing. Lacking authorial capital, translators' manuscripts have not, until recently, appeared in libraries or institutions, and genetic translation studies have therefore focused on a select group of author-translators, including Baudelaire, Beckett, Mallarmé, Nabokov, Pound, and Valéry.

With their art unrecognised and their papers considered to be worthless, translators themselves have rarely kept their own manuscripts or working documents. And even when they do possess such material, they are often reluctant to offer it up to researchers. Durand-Bogaert (2014b, p. 14) recounts her experience of trying to gain access to the papers of at least five major French translators who, even if they acknowledged the value of such material for researchers, nonetheless declined to share it. This suggests that these translators feel the pressure to conform to a model of authorship as inspired genius, preferring to hide their formulations and reformulations, their equivocations and false starts, their corrections and backtrackings, as if to show the mechanisms of their translation would reveal themselves to be less capable of their final, polished version. 
However, two recent trends have contributed to opening up the possibilities for genetic research in translation. The first of these relates to the changing status of the translator and a wider recognition of the importance of translation generally. The rise of translation studies has provoked a broad revaluation within the humanities of the importance of translation for understanding the international transfer of culture and ideas. Certain institutions are responding to this trend and supporting translation research by investing in the collection of translators' manuscripts. Substantial repositories of translators' documents may now be consulted, for instance, at the Lilly Library at Indiana University Bloomington, the Harry Ransom Center at the University of Texas at Austin, the University of East Anglia in the UK, and the Institut Mémoires de l'Édition Contemporaine (IMEC) in Caen, France. Such collections have facilitated a growing number of genetic translation studies, even when, in certain cases, researchers do not situate their methodology or results within the framework of genetic criticism (e.g., Guzmán, 2010, 2014; Munday, 2013).

The second major factor that has allowed for the recent emergence of genetic translation studies is the technological changes within the translator's, not to mention the researcher's, working environment. The effects of the digital revolution are yet to be fully appreciated within genetic translation studies, yet there is no doubt that the digitizing of the translator's workspace offers unprecedented access to his/her avanttextes. The capacity for versions of texts to be saved, stored, categorized and also analysed by computers presents researchers with a new set of theoretical, technological and practical challenges which future genetic translation studies will have to address. They will benefit from advances in emerging but cognate disciplines, such as digital forensics, which specializes in the recovery of information from computers and digital storage; digital information management, which concentrates on strategies of data storage and its exploitation; and computational linguistics, especially corpus linguistics, which enables the linguistic processing of volumes of data that are so large as to be impracticable for non-computerized analysis. Crucial, too, is the normalization of CAT tool use within the profession: as translation technologies are increasingly being integrated into translator training curricula and used in the workplace translators will more and more be producing work that is periodically saved and recorded in the project files of their translations. They will furthermore feel more comfortable using such technologies outside the contexts of pragmatic or technical translation. The fact that the Translation Memory eXchange (TMX) file format is written in the XML computer language means that such genetic information will be able to be exploited by a great number of current and future tools, not to mention multi-skilled genetic translation scholars. Also, democratizing access to the avant-textes of translation through digital editions, websites, or databases is opening up such material to researchers. A case in point is 
the Beckett Digital Manuscript Project (www.beckettarchive.org), which has been pioneering in this field, offering access to the manuscripts of English and French versions of Beckett's bilingual texts while also providing computing tools for the comparative visualization and analysis of those avant-textes.

\section{Towards a genetics of translation}

The articles in this issue of Linguistica Antverpiensia bear witness to scholars staking out the emerging field of genetic translation studies. Using the avant-textes of translation to test, measure and analyse the methods of translation, these studies reorient translation studies in the following ways.

1) They situate the source text within the translation genesis by observing:

- the changes in proximity between translation and source text over the course of the translation's genesis;

- the constraints and conditions that rewriting the source text places upon the translator's work;

- the impact that access to the avant-textes of the source text has upon a translation;

- how parallel genetic studies of source and target texts yield precious evidence for studies comparing the writing of authorship and with the writing of translation.

2) They gauge the varying degrees of the translator's visibility and subjectivity by studying:

- the cognitive processes engaged during the writing of translation;

- the different, but often imbricated processes of the translator's translating and revising;

- the contact between languages during the translation process that generates new hybrid language forms; 
3) They acknowledge translation as a multitasked, interactive process by revealing:

- the collaborative processes that influence a translation (the impact of authors, other translations and translators, friends and colleagues, revisers, editors, online communities);

- the authors' interaction with third parties;

- how translations can feed into or stimulate other creative works of the author-translator.

These studies of avant-textes detail the different strategies and processes of translators who engage at once many of the above questions as they write for different audiences and different media, including print, theatre, film (dubbing) and the internet.

In Eva Karpinski's "Gender, Genetics, Translation: Encounters in the Feminist Translator's Archive of Barbara Godard", manuscript study reveals the importance of author-translator collaboration in Godard's development of a poetics of translation. Karpinski analyses "translation [as] a multidirectional, recursive, and dialogical process of thought and transformation, a creative combination rather than a transparent substitution of meaning", demonstrating the capacity of genetic criticism to thread together the translator's thought processes through their material traces. Such reciprocity between a translator's own genetic strategies and her poetics of translation is explored in Dirk Van Hulle's study of Samuel Beckett's self-translation and the translation into Dutch of James Joyce's Finnegans Wake. Van Hulle identifies five different contexts in which genetic criticism and translation studies can mutually inform each other. These include: (1) when the study of the genesis of the source text aids its translator(s); (2) when the translation calls attention to the textual contingencies of the source text's complex genesis; (3) when the genesis of the source text becomes part of the translation; (4) when the genesis of the translation can complicate its source, not to mention, in the case of a self-translator such as Beckett, cause later editions of the source text to be altered; and (5) when the genetic study of so-called untranslatable texts or phrases renders them comprehensible and thus translatable. Beckett's bilingual writing is contrasted with Joyce's multilingualism, which challenges and modifies "standard" English by accommodating foreign idioms.

Such multilingual practices generate a liminal space between languages, which recalls, for Marie-Hélène Paret-Passos in her contribution, the genetic critic Louis Hay's premise that genetic scholars penetrate "la troisième dimension de la littérature, celle de son devenir, elle nous permet de voir les diverses composantes de l'écriture-socialité 
et individualité, pensée et inconscient, langue et forme-dans la combinatoire mouvante de leurs interactions dont naît le mouvement d'une genèse" (p. 87); literature's third dimension, its becoming, that which allows one to see the various components of writing-sociality and individuality, thought and the unconscious, language and form-in the moving combinatory of their interactions, from which the movement of genesis is born. Hay's concept of a third space inspires Paret-Passos' analogy between genetic study and the processes of translation, the third space of the former comparable to the unique language of translation. Her "Les cahiers de travail d'un traducteur: analyse d'un traduire-écrire. Donaldo Schüler traducteur de James Joyce" generates a dialogue with Henri Meschonnic's theories of translation and reveals Schüler's translation into Portuguese of Finnegans Wake to be a complete, autonomous linguistic recreation. She concludes that, ultimately, Joyce's Wake becomes a sort of language laboratory for the translator.

Elisa Bricco also reads the translator's manuscripts as a kind of laboratory where the space of the translator's hermeneutic work (in progress) becomes most visible. In "Le dossier du traducteur: Giorgio Caproni à l'épreuve de la poésie française", she accounts for Caproni's abandoning a more literal strategy and his adopting a freer translation strategy when returning to revise his translation of André Frénaud's poem "Passage de la Visitation" after many years' absence. She also detects the influence of Caproni's collaboration with the author in his new poetic strategy. Bricco's study therefore enters what Sergio Romanelli terms the "uncensored" space of the manuscript in his contribution "Manuscripts and Translations: Spaces for Creation". Romanelli poses once more the question that was considered for a long time to be self-evident: What is the use of working on material that the translator considered unworthy of publication, the waste product of his/her hesitations, unsuccessful formulations and misunderstandings? For Romanelli, the study of avanttextes allows researchers to access the space where translators dare to experiment, test solutions and make mistakes (be they conscious or unconscious), where they are more comfortable with transcending rules and letting their minds run, where they allow themselves to be, in short, creative. The work inscribed on the page renders the translator a visible agent working within a cultural matrix at the nexus of two or more languages. This is precisely what Romanelli demonstrates when his analysis of the manuscripts of two different translators-Sara Virgillito, who translates Emily Dickinson, and Dom Pedro II, a polyglot and multifaceted translator as well as insatiable student of languages-yields up evidence of a degree of freedom and creativity that is far greater than a translator would ever permit him/herself in his/her published translation.

These articles address, therefore, the specificity of genetic translation studies of written texts. Yet the unique conditions of translating for particular media, be they theatrical, cinematographic, musical, or digital, are equally explored within this issue. 
In "The Pursuit of Beauty by an Aesthete: A Study of Harold Acton's Manuscripts of Popular Chinese Plays" Xingzhong Guan combines a genetic approach with one informed by Poyatos' theory of theatrical translation, "the metamorphosing of multi-sensory images of performance into visually perceived images of writing" (Poyatos quoted in Guan). Guan shows how Harold Acton's translation gradually transforms his text on the page into a text that adapts multi-sensorial images to the demands of the stage. And, as Guan points out, if every translation can be considered a "supplément" in Derrida's (1967, p. 314) sense, a "palingenesis", or regenesis of the original, translation for the stage is a performance that prepares for its onstage rendition, offering a new supplement to the genesis in the form of a set of protocols.

While it may be difficult to imagine a supplement to James Joyce's Ulysses, the work that aspires to channel all of human history into a day, this is exactly what Rosa Maria Bollettieri and Serenella Zanotti discover in "Exploring the Backstage of Translations: A Study of Translationrelated Manuscripts in the Anthony Burgess Archives". They retrace the hypothesized Italian translation of Anthony Burgess's libretto for the musical play Blooms of Dublin, based on James Joyce's Ulysses. Piecing together the complex relationship between six different manuscripts located in Europe and the United States, as well as the roles played by the different individuals involved, they reconstruct the hitherto unknown conditions and phases of manuscript genesis that shaped the translated text's coming into being.

Indeed, a genetic approach to translation exposes the otherwise hidden, collaborative nature of the translator's work. In "Genética del doblaje cinematográfico. La versión del traductor como proto-texto en el filme Rio" ("Genetics of Cinema Dubbing: The Translator's Version as Avant-texte in the Film Rio"), analysing the avant-textes of the Spanish translation of the children's film, Rio, Julio de los Reyes Lozano discovers evidence of different levels of extra-textual communication that are specific to translating for dubbing. Not only are dubbing symbols included to indicate paralinguistic elements of the film, but the translator communicates with his subsequent reader(s) (usually the film's dialogue writer and director) through a series of annotations to the translation that comment upon it, offer multiple propositions and amplifications, or express doubts. De los Reyes demonstrates, therefore, the degree to which the translator of a film for dubbing uses competencies specific to the production of the dubbing track to prepare a text that anticipates the next phase of its realization. This underscores how questions of textual authority and any claim for a translator's auctoritas are very different in this context from those of literary translation in book publishing.

The question of revision and the way it can be integrated into a genetics of translation is taken up by Giovanna Scocchera in "Computerbased Collaborative Revision as a Virtual Lab of Editorial/literary Translation Genetics". She focuses on the digital writing environments in 
which most translators work today, examining especially how computerbased collaborative revision technologies leave traces of the work of revision, which have a direct impact upon the translation.

Regenesis, not only of the source text but of the translation itself, is a phenomenon that translators who post their translations online encounter more and more frequently. In "Methodological Path to the Genesis of a Digital Translation" Lingjuan Fan explores the dynamic, sophisticated interactions that arise when translators submit their work to the scrutiny of readers who are endowed with the capacity to comment upon the translation and are offered a space in which to do so that permits access to the translator. Fan thus stakes out both a challenging and a fascinating new area for genetic translation research, one in which virtual communities of readers provoke changes to translations that evolve with them. Here, the audience thus participates in the genesis of the translation, in real time.

These last two contributions extend the scope of genetic translation studies beyond literary research. They point to the many other forms of translation not addressed in this issue. Indeed, a genetic approach to translation can been adopted for specialized, technical, political, institutional, or commercial texts, or indeed for any other kind of translated text. And while genetic translation studies has inherited a concern with the creative process from its origins in critique génétique, creativity is but one of the many translation processes to which the documents of translation attest. For they offer tangible evidence of a multitude of skills deployed by translators, skills which can be studied in conjunction with other forms of translation process research, including cognitive approaches. It must be stressed that a genetic approach does not imply a return to the hermetic vision of translating that descriptive, cultural, and sociological approaches to translation studies, amongst others, have dispelled. Rather, genetic studies will be able to complement and be informed by cultural and sociological translation research, such that the decisions and processes of the translator are understood to be situated within a network of actors and socio-temporal, economic, political, and institutional factors.

Several contributions in this issue use the working documents of the translator to identify the many hands that contribute to the translation process. They measure the extent to which these different parties influence the published or performed translation, underscoring the need for genetic translation studies to keep step with recent advances in collaborative translation research. Many such studies promote a departure from an inherited model of writing as individual authorship for one constructed around a plurality of actors and processes. Genetic translation studies will thus need to examine not only the decisions of the individual "translator", but those of the institutions, editors, correctors, proofreaders, and clients who each participate differently in the translation process. Furthermore, within literary translation studies, a genetic 
approach can yield powerful insights into the processes of collaborative translation that have hitherto remained unobserved. Even one of the most visible cases of such collaboration-co-translation-has failed to attract much attention from translation scholars, despite the fact that it is a widespread practice. This is attested to, for instance, by the 2015 MLA translation prize, which was delivered to Maureen Freely and Alex Dawe for their English rendition of Ahmet Hamdi Tanpinar's Turkish The Time Regulation Institute, with an honourable mention going to Robert and Elizabeth Chandler for their translation from Russian of Alexander Pushkin's The Captain's Daughter. A better knowledge of the dynamics of co-translation through the study of avant-textes will allow researchers to formulate informed hypotheses with respect to aspects of style and other translation choices, especially where source and target language competency is unevenly distributed between a pair of translators-as is the case, for instance, with Richard Pevear and Larissa Volokhonsky, translators into English of Russian classics, or the French translators of the Chinese Nobel Prize winner Gao Xingjian, Noël and Liliane Dutrait. And while genetic critics have theorized how their methodology can account for the specificities of the theatrical text-examining the stages of writing, rehearsing, performance, and, finally but not necessarily, publication (Léger \& Grésillon, 2006) - they have not made a sustained effort to consider the next phase in its collaborative authorship: translation.

Indeed, the potential for genetic research into the many different kinds of collaborative translation process is vertiginous. The mind boggles, for instance, at the prospect of studying the French translation of the Bible edited by Frédéric Boyer, Marc Sevin and Jean-Pierre Prévost (2001), where twenty francophone writers collaborated with twenty-seven exegetes competent in Hebrew, Aramaic and Greek! Alternatively, along the lines of Eva Karpinski's discoveries in this volume, genetic research into author-translator interactions may witness how intimacy and emotion can complicate the literary lives of authors and translators, which sometimes merge-as was the case with the Portuguese writer José Saramago and his wife and translator into Spanish, Pilar del Río-or become conflictual sites of power and rivalry, as Anokhina (forthcoming) and Hersant (forthcoming) have demonstrated.

\section{Conclusion}

This issue of Linguistica Antverpiensia is testimony to the fact that translators' archives should no longer be considered the curiosities of the scholar or collector but rather essential resources for understanding the processes engaged in the act of translation. Such avant-textes offer a rare opportunity to gauge the different strategies and the different degrees of creativity and autonomy exercised by the translator or translators during 
the writing process. It is becoming clear that the efforts of genetic critics to establish the (relative) autonomy of the avant-texte from that which precedes it is paralleled by the contemporaneous movement within translation studies to establish a concern for translation as independent from its source. Making the case for genetic criticism, Bellemin-Noël (2004, p. 31) employs organic metaphors of filiation, describing avanttextes as the "mothers" of their textual offspring over whose development there are no guarantees. Some genetic translation scholars in this issue follow Scott (2006) in arguing that translation repropagates such a process of generation, reactivating the continuum of textual genesis through a reverse procedure, where the translation unfinishes the source text, rendering it an avant-texte of the translation. Indeed, the practices of translation and genetic research follow similar trajectories, as has been evoked by genetic critics who turn to translation (Bourjea 1995b; DurandBogaert, 2014a). Like translation, it is in the very nature of genetic criticism to unfinish that which seemed to be finished, to destabilize textual authority by submitting a text to its multiple witnesses and incarnations.

This issue of Linguistica Antverpiensia has identified new challenges for genetic translation scholars. It has shown that when researchers study translated texts produced outside the traditional ambit of genetic criticism - literary studies-gaps appear in the methodology which need to be dealt with. Genetic criticism has not, as noted, developed a coherent methodology for accommodating collaborative translation or the digital tools used for producing translations, for subtitling, surtitling, cinema dubbing, and translation for many other media. Nor has it attempted to integrate into its methodology a consideration for how the use of machine translation and translation memories feeds the translation genesis with computer-generated text or text derived from past translation and translators. It has not, more generally, properly considered questions of textual ontology in translation, of the inherent differences between translated texts and nontranslated texts, and how such differences complicate a theory of textual genesis. This special issue has, nonetheless, we hope, offered examples of how this emerging discipline may address the challenges that await it.

\section{References}

Agostini-Ouafi, V., \& Lavieri, A. (Eds.) (2015). Poétiques des archives: genèse des traductions et communautés de pratique [Special issue]. Transalpina, 18.

Anokhina, O. (2015). Les traductions vers l'anglais de Vladimir Nabokov: traduction ou autotraduction? Glottopol, 25, 198-210.

Anokhina, O. (forthcoming). Vladimir Nabokov and his translators: Collaboration or translating under duress. In A. Cordingley \& C. Frigau Manning (Eds.), 
Collaborative translation: From the Renaissance to the digital age. London: Bloomsbury.

Boyer, F., Sevin, M., \& Prévost, J. P. (Eds.). (2001). La Bible: nouvelle traduction. Paris: Bayard.

Barthes, R. (1971). De l'œuvre au texte. Revue d'esthétique, 24(3), 225-232.

Beckett, S. (1976). Proust and three dialogues with Georges Duthuit. London: John Calder. (Original work published 1970.)

Bellemin-Noël J. (1972). Le texte et l'avant-texte: les brouillons d'un poème de Milosz. Paris: Larousse.

Bellemin-Noël J. (2004). Psychoanalytic reading and the avant-texte. In J. Deppman, D. Ferrer, \& M. Groden (Eds.), Genetic criticism: Texts and avant-textes (pp. 28-35). Philadelphia, PA: University of Pennsylvania Press.

Bourjea, S. (Ed.). (1995a). Génétique \& traduction. Paris: L'Harmattan.

Bourjea, S. (1995b). Avant-propos. In S. Bourjea (Ed.), Génétique \& traduction (pp. 5-8). Paris: L'Harmattan.

Bourjea, S. (2000). La Génétique comme traduction. Euvres et Critiques, 25(1), 4962.

Benjamin, W. (2002). The Task of the translator. In M. Bullock \& M. Jennings (Eds.), Selected writings. Vol. 1 1913-1926. Cambridge, MA: The Belknap Press of Harvard University Press.

Contat, M., \& Ferrer D. (Eds). (1998). Pourquoi la critique génétique? Paris: CNRS.

Contini, G. (1970). Varianti e altra linguistica. Torino: Einaudi.

De Biasi, P.-M. (2011). Génétique des textes. Paris: CNRS.

Debray-Genette, R. (1979). Génétique et poétique: le cas Flaubert. In L. Hay (Ed.), Essais de critique génétique (pp. 21-67). Paris: Flammarion.

Deppman, J., Ferrer, D., \& Groden, M. (Eds.). (2004). Genetic criticism: Texts and avant-textes. Philadelphia, PA: University of Pennsylvania Press.

Derrida, J. (1967). L'Ècriture et la différence. Paris: Seuil.

Dillen, W., Caroline, M., \& Van Hulle, D. (Eds.). (2012). Texts beyond borders: Multilingualism and textual scholarship [Special issue]. Variants: The Journal of the European Society for Textual Scholarship, 9. Amsterdam: Rodopi.

Durand-Bogaert, F. (Ed.). (2014). Traduire [Special issue]. Genesis, 38.

Durand-Bogaert, F. (2014a). Présentation: ce que la génétique dit, la traduction le fait. Traduire [Special issue]. Genesis, 38, 7-10.

Durand-Bogaert, F. (2014b) Les deux corps du texte. Traduire [Special issue]. Genesis, 38, 11-33.

Ferrer, D. (2002). Production, invention and reproduction: Genetic vs. textual criticism. In E. Bergmann Loizeaux \& N. Fraistat (Eds.), Reimagining textuality: Textual studies in the late age of print (pp. 48-59). Madison, WI: University of Wisconsin Press.

Ferrer, D. (2010a). Avant-texte. Dictionnaire de Critique Génétique. www.item.ens.fr. Accessed 20 October 2015.

Ferrer, D. (2010b). Critique génétique et philologie: racine de la différence. Genesis, 30, 21-23.

Ferrer, D. (2011). Logiques du brouillon: modèles pour une critique génétique. Paris: Seuil. 
Folena, G. (1994). Volgarizzare e tradurre. Torino: Piccola Biblioteca Einaudi.

Grésillon, A. (1994). Eléments de critique génétique. Paris: PUF.

Greetham, D. C. (1994). Textual scholarship: An introduction. Garland Reference Library of the Humanities 1417. New York, NY: Garland. (Originally published in 1992.)

Hay, L. (1989). La Naissance du texte. Paris: José Corti.

Hay, L. (1993). Les Manuscrits des écrivains. Paris: Hachette, CNRS.

Hartmann, E. C. (2000). Histoire d'une traduction. Souffles de Perse, 9, 11-27.

Hersant, P. (forthcoming). Author-translator collaborations: A typological survey. In A. Cordingley \& C. Frigau Manning (Eds.), Collaborative translation: From the Renaissance to the digital age. London: Bloomsbury.

Hokenson, J. H., \& Munson, M. (2007). The bilingual text: History and theory of literary self-translation. Manchester: St. Jerome.

Jeannelle, J. L., \& Catherine V. (Eds.). (2007). Genèse et autofiction. Louvain-laNeuve: Academia Bruylantj.

Lebrave, J.-L. (1992). La Critique génétique: une discipline nouvelle ou un avatar moderne de la philologie? Genesis, 1, 33-72.

Léger, N., \& Grésillon, A. (Eds.). (2006). Théâtre [Special issue]. Genesis, 26.

Gama, M., \& Amigo Pino, C. (Eds.) (2011). Tradução [Special issue]. Manuscrítica. Revista de Crítica Genética, 20.

Grando, C. (2001). Genética e tradução: A poética de Hilda Hilst. Manuscrítica. Revista de Crítica Genética, 10, 141-153.

Guzmán, M. C. (2010). Gregory Rabassa's Latin American literature: A translator's visible legacy. Lewisburg, PA: Bucknell University Press.

Guzmán, M. C. (2014). Translation north and south: Composing the translator's archive. In H. Buzelin \& A. Nouss (Eds.), Translating concepts in human and social sciences: Around Daniel Simeoni's thinking [Special issue]. TTR, $27(1)$.

Montini, C. (2015) (Ed.). Traduire: genèse du choix. Paris: Éditions des archives contemporaines.

Munday, J. (2013). The role of archival and manuscript research in the investigation of translator decision-making. Target. International Journal of Translation Studies, 25(1), 125-139.

Paret-Passos, M.-H. (2011). Da crítica genética à tradução literária: Uma interdisciplinaridade. Vinhedo: Editora Horizonte.

Proust, M. (1998). Le temps retrouvé. Vol. IV. Paris: Pléiade, Gallimard.

Romanelli, S. (2013a). Gênese do processo tradutório. Vinhedo: Editora Horizonte.

Romanelli, S., Soares, G. N., \& de Souza, R., (Eds.). (2013). Dom Pedro II: Um tradutor imperial. Florianópolis: Editora Copiart.

Sardin-Damestoy, P. (2002). Samuel Beckett, autotraducteur ou l'art de l'«empêchement ». Artois: Presses Universitaires d'Artois.

Scott, C. (2006). Translating the literary: Genetic criticism text theory and poetry. In S. Bassnett \& P. Bush (Eds.), The translator as writer (pp. 106-117). London: Continuum.

Van Hulle, D. (2014). Modern manuscripts: The extended mind and creative undoing from Darwin to Beckett and beyond. London: Bloomsbury. 
Van Hulle, D., \& Weller, S. (2014). The making of Samuel Beckett's 'L'Innommable' / 'The Unnamable'. London: Bloomsbury.

Willemart, P. (2007). Critique génétique: pratiques et théories. Paris: L’Harmattan.

Zular, R. (Ed.). (2000). Criação em processo: Ensaio de crítica genética. São Paulo: Iluminuras.

1 Genetic criticism is at present experiencing a resurgence of interest in countries as diverse as Belgium (especially through the work of the Centre for Manuscript Genetics at the University of Antwerp), Brazil (with its Association of Researchers in Genetic Criticism), Britain, Italy and China.

2 The notable exception here is the self-translator, whose "translations" benefit from the status of his or her authorship (Hokenson \& Munson, 2007). 